\title{
Progesterone Receptor Positive by Immunohistochemistry
}

National Cancer Institute

\section{Source}

National Cancer Institute. Progesterone Receptor Positive by Immunohistochemistry.

NCl Thesaurus. Code C141458.

An immunohistochemical staining finding indicating that cells in a tissue sample are expressing progesterone receptor. 